\title{
The Crafts in Interdisciplinary Curriculum in School
}

\author{
Karppinen, Seija
}

Routledge

2018

Karppinen , S 2018, The Crafts in Interdisciplinary Curriculum in School . in E Garber , L Hochtritt \& M Sharma (eds), Makers, Crafters, Educators : Working for Cultural Change . Routledge, New York, pp. 119-122.

http://hdl.handle.net/10138/322009

acceptedVersion

Downloaded from Helda, University of Helsinki institutional repository.

This is an electronic reprint of the original article.

This reprint may differ from the original in pagination and typographic detail.

Please cite the original version. 
Karppinen, S. (2018) The Crafts in Interdisciplinary Curriculum in School. In E. Garber, L. Hochtritt, \& M. Sharma (Eds.), Makers, crafters, educators: Working for cultural change. New York, NY: Routledge.

\section{The Crafts in Interdisciplinary Curriculum in School}

Seija Karppinen

In many countries crafts and making can be more often found in informal environments than in schools. However, in some of the North European schools, for example, craft is still a vigorous school subject that includes designing and constructing products using digital and traditional techniques, whereas, in some countries it might be blended into nearby disciplines (e.g., the visual arts, design, or technology). Craft's new approaches, like invention pedagogy, maker culture, out-of-school learning, coding and robotics, and interdisciplinary pedagogy (STEAM-based approaches, for example) are gaining ground in schools and curricula, encouraging students to innovate, collaborate in knowledgecreating, and learn by making (Blikstein, Seitamaa-Hakkarainen and Hakkarainen, Karppinen et al. "Interdisciplinary Integration," Kallunki et al.). Interdisciplinary pedagogy also highlights a variety of physical learning spaces and use of what is locally available is welcome and recommended (e.g., Finnish National Core Curriculum, Wilenius 170; Lipponen and Rönnholm 64).

\section{Interdisciplinary Approach}

An interdisciplinary approach refers not only to learning themes across disciplines, but refers to their relationship with the real world and an understanding of connections. As early as the 1840s William Whewell introduced a concept of consilience, which means the "linking of facts and fact-based theory across disciplines to create a common groundwork of explanation," i.e., to find what they share in common and then create a complete picture (Wilson 9). More recently, constructivists and socio- 
constructivists, primarily working from the thoughts of Lev Vygotsky, have discussed that learning is an active process where people construct their own understanding and knowledge in social interaction. Today's making-based pedagogy lays much emphasis on John Dewey's "learning by doing” and Seymour Papert's "learning by making" practices and underlines collaboration, project-based and inquiry-driven education, especially in the STEAM disciplines (e.g., Blikstein, Osborne and Dillon, Viilo, Seitamaa-Hakkarainen and Hakkarainen). Integrating making activity into a school curriculum offers a favorable environment for answering the challenges of the $21^{\text {st }}$ century, multiliteracy, and engaging students in a meaningful making and innovation education. For instance, maker spaces like the FabLearn labs (Stanford University, U.S.A.) and Co4-Labs (University of Helsinki, Finland) support development of socio-digital invention pedagogy in schools and school-university cooperation. In addition, teachers need their own labs for in-service training (see, e.g., The Mind Lab/Unitec).

\section{Maker Culture}

Maker culture has created environments like maker clubs, makerspaces, and the Maker Movement for people to gather, share resources and knowledge, work on projects, learn about technology, solve problems, and build (ELI, Rosenfeld Harverson and Sheridan). These kinds of making spaces nowadays have an increasing potential in schools. Maker culture that engages people in do-ityourself (DIY) and do-it-with-others (DIWO) techniques and processes to develop unique products inspires students to become makers instead of just users. The value of maker culture has risen in the new millennium, which is overloaded with rapidly developing digital technologies and offers opportunities toward unrevealed invention and innovation. 


\section{Invention Pedagogy and Making in School}

Alongside digitization and technological development, crafts and making have gained new and interesting dimensions, equipment, and methods, such as 3D printers, laser cutters, robotics, coding, etextiles, smart clothes, and wearable technology. These new tendencies have opened novel possibilities for making and innovating in schools, balanced with both sensible costs and resources (Karppinen et al. 'Interdisciplinary Craft'). For example, a knitted cap with Bluetooth earphones combines traditional craft with new technology. A unique artifact can be created by combining sewing and embroidery techniques with coding using conductive metallic thread or a piece of fabric, LED Neopixel Ring, and a microcontroller (e.g., Flora or Gemma) for programming the LED lights (e.g., using Arduino) to change color in certain situations, environmental conditions or acts (e.g., sound, music, gesture, knocking; see figure 1). A simple way to light a single LED is to use a battery, a magnet, and electric wire, and all this can be integrated into an artifact. New technologies also enable participants to fabricate virtually any artifacts, and even young children can construct complex controllable artifacts with hybrid material and virtual features (Seitamaa-Hakkarainen and Hakkarainen).

These types of making activities where creativity, sharing, invention, and imagination are at the focus describe today's education in Finland (Lipponen and Rönnholm 30; Wilenius 2015, 169) and all over the world and may, in the best cases, increase students' motivation in doing school work and enhance school satisfaction. Making culture's initiation into schools could also be a response to Jonathan Osborne's and Justin Dillon's statement that students lack an interest in science education. Moreover, student-centered self-piloting and lateral learning, as opposed to a top-down model, is a much more authentic representation of how learning happens in everyday life. 


\section{Works Cited}

Blikstein, Paolo. "Digital Fabrication and 'Making' in Education: The Democratization of Innovation," 2013. /tltl.stanford.edu/sites/default/files/files/documents/publications/2013.Book-B.Digital.pdf. Accessed 6 February 2017.

ELI (Educause Learning Initiative). "7 Things You Should Know About Makerspaces,” 2013. . net.educause.edu/ir/library/pdf/eli7095.pdf. Accessed 6 February 2017.

Finnish National Core Curriculum for Basic Education. "Finnish National Board of Education," 2014.oph.fi/download/163777_perusopetuksen_opetussuunnitelman_perusteet_2014.pdf (in Finnish); http://oph.fi/english/curricula_and_qualifications/basic_education/curricula_2014 (in English). Accessed 15 January 152017.

Halverson, Erica Rosenfeld, and Kimberly Sheridan. "The Maker Movement in Education." Harvard Educational Review, vol. 84, no. 4,2014, pp.495-504.

Kallunki, Veera, Seija Karppinen, and Kauko Komulainen "Becoming Animated of Teaching Physics, Crafts, and Drama Together - A Multidisciplinary Course for Class Teacher Students." Journal of Education for Teaching, vol. 43, no. 1, 2017, pp. 1360-0540. DOI 10.1080/02607476.2016.1182373.

Karppinen, Seija, Veera Kallunki, Seija Kairavuori, Kauko Komulainen, and Sara Sintonen. "Interdisciplinary Integration in Teacher Education." In Interaction in Educational Domains 2013, edited by Kirsi Tirri and Elina Kuusisto. Sense Publishers, 2013, pp. 149-158.

Karppinen, Seija, Veera Kallunki, and Kauko Komulainen "Interdisciplinary Craft Designing and Invention Pedagogy in Teacher Education: Smart Textiles and Wearable Technology," International Journal of Technology and Design Education 2017. DOI 10.1007/s10798-0179436-x.

Lipponen, Päivi, and Antton Rönnholm. Pulpetista tablettiin [From Desk to Tablet]. Polemia no. 102. Pole-Kuntatieto Oy, 2016.

Osborne, Jonathan, and Justin Dillon. Science Education in Europe: Critical Reflections. King's College London, 2008.

Seitamaa-Hakkarainen, Pirita, and Kai Hakkarainen. 'Learning by Making.' In The SAGE Encyclopedia of Out-of-School Learning 2017, edited by Kylie Peppler. Sage Publications, 2017, pp. 421-424.

Viilo, Marjut, Pirita Seitamaa-Hakkarainen, and Kai Hakkarainen. "Infrastructures for TechnologySupported Collective Inquiry Learning in Science." In Orchestrating Inquiry Learning: Contemporary Perspectives on Supporting Scientific Inquiry Learning 2011, edited by Karen Littleton, Eileen Scanlon, and Mike Sharples. Routledge, 2011, pp. 128-145.

Wilenius, Markku. Tulevaisuuskirja. Metodi seuraavan aikakauden ymmärtämiseen. [Book of the Future. Method to Understand the New Era]. Otava, 2015.

Wilson, Edward O. Consilience. The Unity of Knowledge. Random House, 1999. 